Glaxo Group Research Limited for providing ranitidine and placebo and performing the ranitidine assay.

1 Allan R, Dykes P. A study of the factors influencing mortality rates from gastrointestinal haemorrhage. Qf $\mathrm{Med}$ 1976;180:533-50.

2 Jones FA. Haematemesis and melaena with special reference to causation and to the factors influencing the mortality from bleeding peptic ulcers. Gastroenterology 1956;30:166-90.

${ }^{3}$ MacDougall BRD, Bailey RJ, Williams $\mathrm{R}$. $\mathrm{H}_{2}$ receptor antagonists and antacids in the prevention of acute gastrointestinal haemorrhage in fulminant hepatic failure. Lancet $1977 ; \mathrm{i}: 617-9$.

${ }^{4}$ LaBrooy SJ, Misiewicz JJ, Edwards T, et al. Controlled trial of cimetidine in upper gastrointestinal haemorrhage. Gut 1979;20:892-5.

${ }^{5}$ Domschke W, Lux G, Domschke S. Furan $\mathrm{H}_{2}$-antagonist ranitidine inhibits pentagastrin stimulated gastric secretion stronger than cimetidine. Gastroenterology 1980;79:1267-71.

(Accepted 18 May 1982)

Division of Medicine, Selly Oak Hospital, Birmingham B29 6JD

JOHN DAWSON, BM, MRCP, senior registrar (present address: department of medicine, Queen Elizabeth Hospital, Birmingham B15)

ROY COCKEL, MB, FRCP, consultant physician

\section{Paralytic ileus and urinary retention due to hypothyroidism}

Peripheral neuropathy is a recognised complication of hypothyroidism. Skeletal muscles, the intestines, and the urinary tract may all be affected. We report an unusual case in which the patient presented with paralytic ileus and bladder retention, and despite biochemical evidence of severe hypothyroidism physical signs of myxoedema were absent. The patient eventually responded to replacement treatment.

\section{Case report}

A 67-year-old woman was admitted with a history of increasing malaise, constipation, difficulty with walking, and urinary incontinence. On examination she was dehydrated and had a distended, tympanic abdomen with scanty bowel sounds. The bladder was palpable above the umbilicus and this was confirmed radiologically (see figure). She had global muscle wasting with profound weakness of limb and facial muscles. External signs of myxoedema were absent. She had a normochromic, normocytic anaemia (haemoglobin concentration $8 \mathrm{~g} / \mathrm{dl})$ due to combined folate $(1 \cdot 1 \mu \mathrm{g} / \mathrm{l})$ and iron $(690 \mu \mathrm{g} / \mathrm{l})$ deficiencies. Plasma urea $(22 \mathrm{mmol} / \mathrm{l})$ and creatinine $(194 \mu \mathrm{mol} / \mathrm{l})$ concentrations were both raised. Urine microscopy showed red and white blood cells, and urine culture grew Escherichia coli. Intravenous urography indicated bilateral hydronephrosis with a distended bladder. A barium enema showed severe dilatation of the large intestine with no obvious physical obstruction, an appearance typical of intestinal pseudoobstruction. Electromyographic findings were typical of a severe, predominantly motor polyneuropathy. Thyroid function tests indicated severe primary hypothyroidism with a serum thyroxine concentration of $<10 \mathrm{nmol} / 1$, and a raised thyroid-stimulating hormone concentration of $45 \mathrm{mU} / 1$.

We considered her diagnosis to be hypothyroid polyneuropathy affecting her intestines, urinary tract, and skeletal muscles. Despite intravenous rehydration, blood transfusion, urinary catheterisation, and the administration of thyroxine her condition continued to deteriorate. Nasogastric and rectal suction were begun, together with intravenous hyperalimentation and intravenous triiodothyronine (up to $60 \mu \mathrm{g} /$ day). This regimen had to be continued for eight weeks before the patient could receive a conventional diet, but her recovery thereafter was uninterrupted. The paralytic ileus resolved and micturition returned to normal, as did her gait. Repeat barium studies and intravenous urography showed no abnormality. She was discharged home feeling well, taking only oral thyroxine $(200 \mu \mathrm{g} /$ day $)$.

\section{Comment}

Though combined intestinal and urinary tract involvement in hypothyroidism has previously been reported, the combination of "internal myxoedema" together with a skeletal polyneuropathy has not been described. Ord, ${ }^{1}$ in an early description of myxoedema in 1879 , described necropsy findings including widespread connective tissue infiltration with mucoid degeneration in nervous and muscular tissue. More recently, Wells $e t a^{2}$ suggested that the intestinal component was caused by an autonomic polyneuropathy with Schwann cell degeneration possibly due to mucopolysaccharide deposition; the

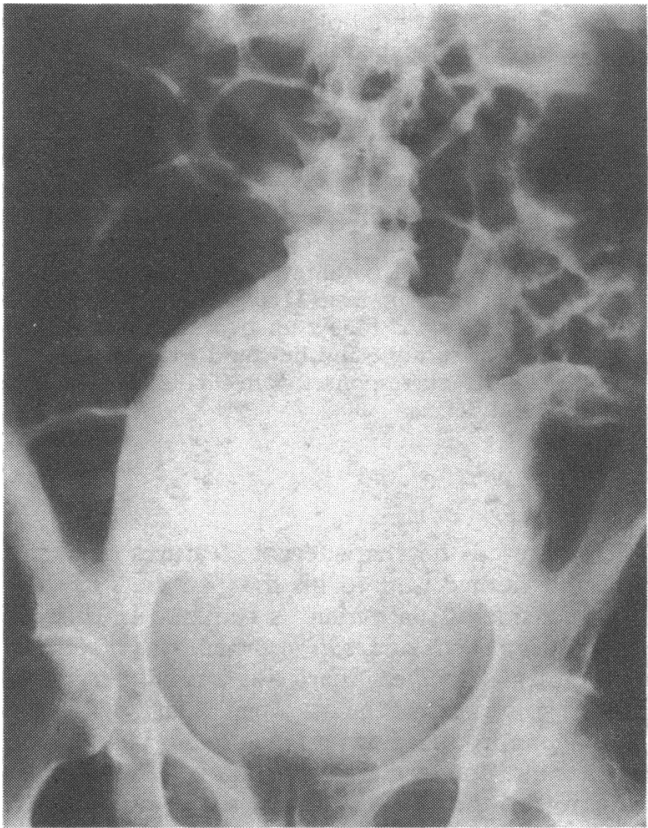

Supine plain abdominal $x$-ray film showing bladder distension and dilated loops of large and small intestine.

innervation to skeletal muscles and the urinary tract musculature may be similarly affected.

The peripheral and autonomic neuropathy of hypothyroidism may take many weeks to recover, but even severe atony of the bladder and paralytic ileus are eventually reversible. It is important to consider hypothyroidism as a cause of autonomic or peripheral neuropathy even in the absence of overt signs of myxoedema.

Correspondence and requests for reprints should be addressed to: Dr $A$ W Nathan, Department of Cardiology, St Bartholomew's Hospital, London EC1A 7BE.

1 Ord WM. Report of the Clinical Society of London. Lancet $1879 ; \mathrm{ii}: 577-9$.

2 Wells I, Smith B, Hinton M. Acute ileus in myxoedema. Br Med 7 1977; i:211-2.

(Accepted 11 May 1982)

Royal Free Hospital, London NW3 2QG

A W NATHAN, MB, MRCP, medical registrar

C W H HAVARD, MD, FRCP, consultant physician

\section{Motor spastic paraplegia and unilateral infranuclear facial palsy complicating tetanus}

We describe a patient with tetanus who developed a purely motor spastic paraplegia and left facial palsy, both of which resolved completely.

\section{Case report}

A 20-year-old man was admitted to hospital in October 1980 with a threeday history of body stiffness and inability to stand and asymmetry of the face for the previous two days. He had injured his right foot 15 days before. There was no history of head injury, discharge from the ears, or eating seeds of Lathyrus sativus. Examination showed a blood pressure of $130 / 80 \mathrm{~mm} \mathrm{Hg}$, lockjaw, abdominal rigidity, and opisthotonos. He was also having frequent tetanic spasms. Facial asymmetry was due to left-sided facial palsy and spasm of facial muscles on the right, giving the appearance of a hemirisus sardonicus. Hearing and taste were normal. Neurological examination showed purely motor, upper motor neurone spastic paraplegia with hyper- 